\title{
Ktenasite from the Hirao mine at Minoo, Osaka, Japan
}

\author{
Masayuki OHNISHI*, Shoichi KOBAYASHI** and Isao KUSACHI*** \\ *Department of Chemistry and Bioscience, College of Science and Industrial Technology, \\ Kurashiki University of Science and the Arts, Kurashiki 712-8505, Japan \\ ** Division of Earth Sciences, Kurashiki University of Science and the Arts, Kurashiki 712-8505, Japan \\ *** Department of Earth Sciences, Faculty of Education, Okayama University, Okayama 700-8530, Japan
}

\begin{abstract}
Ktenasite was found as a vein forming mineral in the altered shale of Tamba zone of Jurassic age, at the Hirao mine, Minoo, Osaka, Japan. The mineral was also found in a marginal part of sphalerite in the host rock. This is the first occurrence of ktenasite in Japan. Ktenasite occurred as aggregates of flattened prismatic crystals up to $0.5 \mathrm{~mm}$ long and $0.1 \mathrm{~mm}$ wide, in association with minerals such as chalcopyrite, serpierite, smithsonite, hydrozincite, and limonite. An EPMA and CHNS/O analyzer gave the empirical formula $\left(\mathrm{Cu}_{3.446} \mathrm{Zn}_{1.451} \mathrm{Co}_{0.080}\right.$ $\left.\mathrm{Pb}_{0.018} \mathrm{Ni}_{0.007}\right)_{25.002}\left(\mathrm{SO}_{4}\right)_{2.003}(\mathrm{OH})_{5.998} \cdot 5.99 \mathrm{H}_{2} \mathrm{O}$ on the basis of $\mathrm{O}=20$. The unit cell parameters were $a=5.590(1)$, $b=6.161(1), c=23.741(3) \AA$, and $\beta=95.628(3)^{\circ}$. The Vickers microhardness was $113 \mathrm{~kg} / \mathrm{mm}^{2}$ and Moh's hardness was 2.5 . The density was $2.93 \mathrm{~g} / \mathrm{cm}^{3}$. It is likely that ktenasite at Minoo was formed by a reaction of the Cu-bearing fluids with sphalerite.
\end{abstract}

\section{Introduction}

Ktenasite was originally found as a new mineral at the Kamaresa mine in Lavrion, Greece by Kokkoros (1950). It occurred sparingly as blue-green platy crystals up to 1 $\mathrm{mm}$ in association with smithsonite, glaucocerinite and serpierite. The mineral was also reported by Rankin (1969) from the Ecton mine, Montgomery County, Pennsylvania, but no data were given, and there must be doubt as to the identification. A green platy mineral from the Glomsrudkollen zinc mine, Modum, Norway was identified as ktenasite by Raade et al. (1977), who proposed the ideal chemical formula $(\mathrm{Cu}, \mathrm{Zn})_{5}\left(\mathrm{SO}_{4}\right)_{2}$ $(\mathrm{OH})_{6} \cdot 6 \mathrm{H}_{2} \mathrm{O}$. Subsequently, the mineral was described from Contrada Trentini, Italy and the Drakewall mine, Cornwall by Mellini et al. (1981) and from the Tui mine, Te Aroha, New Zealand by Courtney and Rodgers (1990). Mellini and Merlino (1978) determined the structure of ktenasite from Miniera Trentin, Italy. Olsen and Lewis (1979) reported that ktenasite from Creede, Colorado was richer in zinc than copper. The zinc analogue of ktenasite was also found from the Smallcleugh and Brownley Hill mines, Cumbria by Livingstone (1991). Moreover, cobaltoan nickeloanktenasite was found at Cap Garonne, France by Sarp et al. (1990).

During a mineralogical survey of the Hirao mine at Minoo, Osaka, ktenasite was found. This is the first

S. Kobayashi, shoichi@las.kusa.ac.jp Corresponding author

I. Kusachi, kusachi@cc.okayama-u.ac.jp occurrence of ktenasite to be reported in Japan. The present paper deals with its mode of occurrence and mineralogical properties.

\section{Occurrence}

The Hirao ore deposit is located in shale belonging to Tamba zone of the Jurassic age in Minoo, in the northern part of Osaka. The deposit had been worked for zinc and copper. The host rock has been greatly altered by a hydrothermal solution. The ore and gangue minerals found in the gallery include sphalerite, chalcopyrite, pyrite, galena, calcite, quartz, limonite, gypsum, smithsonite, hydrozincite, aragonite, schulenbergite, brianyoungite, hemimorphite, serpierite, ramsbeckite, brochantite, and aurichalcite. These minerals have been summarized in Ohnishi et al. (2001).

Ktenasite occurs as aggregates of flattened prismatic crystals up to $0.5 \mathrm{~mm}$ in length. The mineral was divided into two types according to the mode of occurrence. The first type occurs as a vein forming mineral in association with serpierite, smithsonite, hydrozincite, limonite, sphalerite and chalcopyrite in an altered Jurassic formation. The veins cut through the host rock and nodules up to $1 \mathrm{~m}$ in size in the host rock, which were composed mainly of sphalerite and a small amount of chalcopyrite. The width of the veins is up to $1 \mathrm{~mm}$. The second type occurs in a marginal part of sphalerite in the host rock. A photomicrograph of ktenasite of the second type associated with sphalerite is shown in Figure 1. 


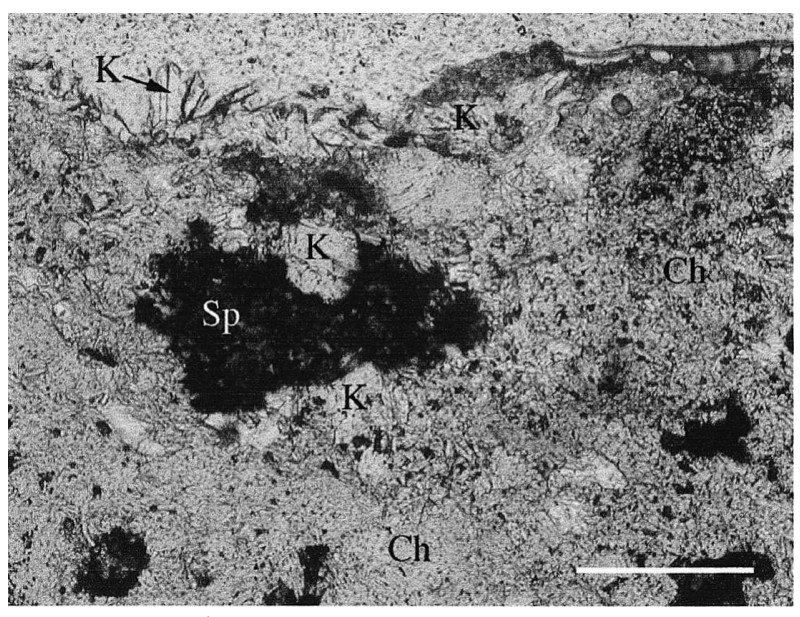

Figure 1. Photomicrograph of ktenasite from Minoo. Abbreviations: $\mathrm{K}$, ktenasite; $\mathrm{Sp}$, sphalerite; $\mathrm{Ch}$, chlorite. Scale bar indicates 0.2 $\mathrm{mm}$.

\section{Physical and optical properties}

Ktenasite is emerald green to pale green with a vitreous luster in hand specimen, and colorless in thin section. The density measured by heavy liquid is $2.93 \mathrm{~g} / \mathrm{cm}^{3}$.
The Vickers microhardness and Moh's hardness are 113 $\mathrm{kg} / \mathrm{mm}^{2}$ (10g load) and 2.5 , respectively. These properties are in agreement with those reported by Kokkoros (1950) and Raade et al. (1977). The mineral exhibits a perfect $\{001\}$ cleavage in the same manner as that reported by Mellini and Merlino (1978) and Adiwidjaja et al. (1996).

The infrared (IR) absorption spectrum of ktenasite was measured by the $\mathrm{KBr}$ method for the region 4000 to $250 \mathrm{~cm}^{-1}$, as shown in Figure 2. The absorption band at $3580 \mathrm{~cm}^{-1}$ is attributed to $\mathrm{OH}$ stretching vibration. Broad bands at 3420 and $1630 \mathrm{~cm}^{-1}$ are due to stretching and bending vibrations of $\mathrm{H}_{2} \mathrm{O}$, respectively. Several absorption bands in the region 1000 to $1200 \mathrm{~cm}^{-1}$ and numerous low frequency bands are attributed to the vibrations of $\left[\mathrm{SO}_{4}\right]$ tetrahedra and $\left[(\mathrm{Cu}, \mathrm{Zn}) \mathrm{O}_{6}\right]$ octahedra, respectively. The IR spectrum is in agreement with those showed by Raade et al. (1977), Courtney and Rodgers (1990) and Livingstone (1991).

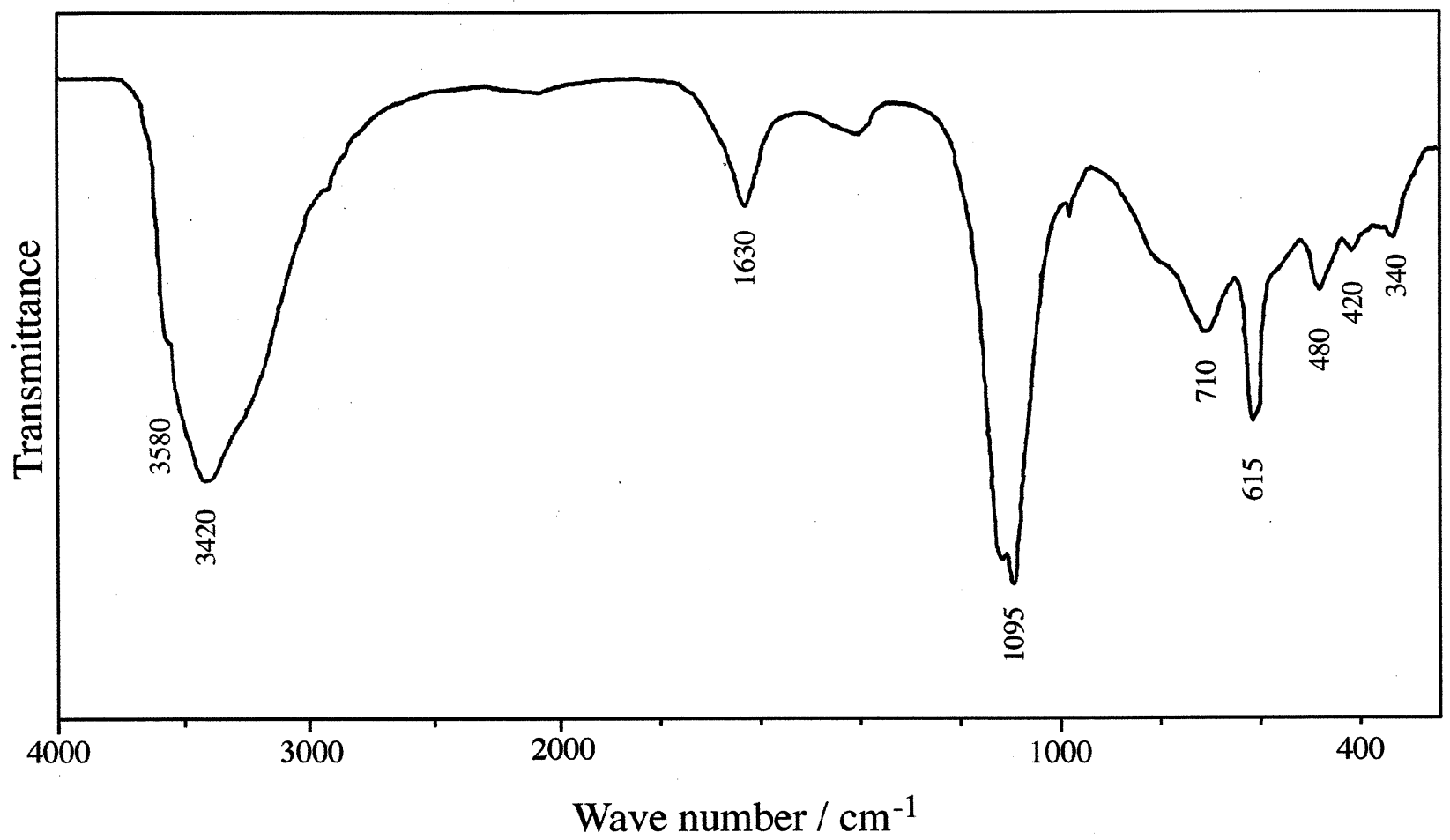

Figure 2. Infrared absorption spectrum of ktenasite from Minoo. 
Table 1. X-ray powder diffraction data for ktenasite

\begin{tabular}{|c|c|c|c|c|c|c|c|c|c|c|c|c|c|c|c|}
\hline & & & 1 & & & 2 & & & & & 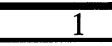 & & & 2 & \\
\hline$h$ & $k$ & $\bar{l}$ & $d$ calc & $d$ meas & $I$ & $d$ & $I$ & $h$ & $k$ & $l$ & $d$ calc & $d$ meas & $I$ & $d$ & $I$ \\
\hline 0 & 0 & 2 & 11.82 & 11.79 & 100 & 11.82 & 100 & 2 & 2 & 0 & 2.06 & & & & \\
\hline 0 & 1 & 1 & 5.96 & 592 & 52 & 593 & 85 & $\frac{5}{2}$ & 2 & 2 & 2.06 & & & & \\
\hline 0 & 0 & 4 & 5.91 & 5.92 & 52 & 5.93 & 85 & 1 & 2 & 7 & 2.06 & 2.06 & 3 & 2.061 & 10 \\
\hline 0 & 1 & 2 & 5.46 & & & 5.44 & 5 & 2 & 1 & 6 & 2.05 & & & & \\
\hline 1 & 0 & 2 & 4.85 & & & & & 0 & 3 & 1 & 2.05 & & & & \\
\hline 0 & 1 & 3 & 4.85 & 4.86 & 40 & 4.85 & 90 & 2 & 2 & 1 & 2.04 & & & & \\
\hline$\overline{1}$ & 0 & $\begin{array}{l}4 \\
4\end{array}$ & $\begin{array}{l}4.26 \\
426\end{array}$ & 4.26 & 10 & 4.26 & 15 & $\frac{\overline{1}}{2}$ & $\begin{array}{l}2 \\
2\end{array}$ & $\begin{array}{l}8 \\
3\end{array}$ & $\begin{array}{l}2.04 \\
2.03\end{array}$ & 2.04 & 2 & 2.037 & 5 \\
\hline $\begin{array}{l}0 \\
1\end{array}$ & $\begin{array}{l}1 \\
1\end{array}$ & $\begin{array}{l}4 \\
0\end{array}$ & $\begin{array}{l}4.20 \\
4.13\end{array}$ & 4.12 & 16 & 4.12 & 30 & $\begin{array}{l}2 \\
0\end{array}$ & $\begin{array}{l}2 \\
1\end{array}$ & $\begin{array}{r}3 \\
11\end{array}$ & $\begin{array}{l}2.03 \\
2.03\end{array}$ & & & & \\
\hline$\frac{1}{1}$ & 1 & 1 & 4.12 & & & & & $\frac{5}{2}$ & 1 & 8 & 2.01 & & & & \\
\hline 1 & 1 & 1 & 4.02 & & & 4.02 & 10 & 2 & 2 & 2 & 2.01 & 2.01 & 5 & 2.008 & 5 \\
\hline 0 & 0 & 6 & 3.94 & 3.94 & 18 & 3.947 & 20 & 0 & 2 & 9 & 2.00 & & & & \\
\hline 1 & 0 & 4 & 3.86 & & & 3.881 & 10 & $\underline{0}$ & 0 & 12 & 1.969 & & & & \\
\hline$\underline{0}$ & 1 & 5 & 3.75 & 3.75 & 17 & 3.754 & 20 & $\overline{1}$ & 1 & 11 & 1.965 & 1.967 & 3 & & \\
\hline$\overline{1}$ & 0 & 6 & 3.37 & 3.37 & 6 & 3.377 & 15 & 2 & 2 & 3 & 1.962 & & & 1.962 & 5 \\
\hline$\overline{1}$ & 1 & 5 & 3.23 & 3.23 & 3 & 3.227 & 5 & $\overline{2}$ & 2 & 5 & 1.944 & & & 1.941 & 5 \\
\hline 0 & 2 & 0 & 3.08 & 3.08 & 4 & 3.083 & 10 & & & & & & & 1.926 & 10 \\
\hline 1 & 0 & 6 & 3.07 & & & 3.067 & 10 & $\overline{1}$ & 0 & 12 & 1.916 & & & 1.920 & 5 \\
\hline 0 & 1 & 7 & 2.96 & & & & & 2 & 2 & 4 & 1.906 & & & 1.907 & 5 \\
\hline$\overline{1}$ & 1 & 6 & 2.96 & 2.96 & 23 & 2.955 & 50 & $\overline{1}$ & 3 & 3 & 1.886 & 1887 & $?$ & & \\
\hline 0 & 0 & 8 & 2.95 & & & & & $\overline{2}$ & 2 & 6 & 1.886 & 1.001 & 2 & & \\
\hline 2 & 0 & 0 & 2.78 & 2.78 & 15 & 2.785 & 60 & 0 & 1 & 12 & 1.875 & & & 1.879 & 5 \\
\hline$\overline{1}$ & 1 & 7 & 2.71 & & & & & 1 & 2 & 9 & 1.837 & 1.838 & 1 & 1.838 & 5 \\
\hline 1 & 2 & 0 & 2.69 & 2.70 & 18 & 2.688 & 60 & $\overline{1}$ & 3 & 5 & 1.806 & & & & \\
\hline$\overline{1}$ & 2 & 1 & 2.69 & & & & & 3 & 0 & 2 & 1.805 & 1.805 & 1 & 1.804 & 5 \\
\hline 1 & 2 & 1 & 2.66 & & & & & 1 & 0 & 12 & 1.801 & & & & \\
\hline 0 & 1 & 8 & 2.66 & 266 & 11 & 2655 & 50 & $\overline{3}$ & 0 & 3 & 1.768 & 1.766 & 2 & 1.768 & 5 \\
\hline$\overline{1}$ & 2 & 2 & 2.65 & 2.00 & 11 & 2.655 & 50 & $\overline{3}$ & 1 & 4 & 1.746 & 1746 & 5 & 1745 & 10 \\
\hline$\underline{2}$ & 0 & 2 & 2.65 & & & & & $\underline{\overline{3}}$ & 0 & 6 & 1.745 & 1.140 & & 1.145 & 10 \\
\hline$\overline{2}$ & 0 & 4 & 2.62 & & & 2.620 & 5 & $\overline{1}$ & 2 & 11 & 1.720 & 1.720 & 5 & 1.720 & 10 \\
\hline 1 & 2 & 2 & 2.60 & & & & & 2 & 0 & 10 & 1.719 & 1.720 & 5 & 1.720 & 10 \\
\hline$\overline{1}$ & 2 & 3 & 2.59 & 2.59 & 23 & 2.584 & 70 & $\underline{0}$ & 0 & 14 & 1.688 & 1687 & 3 & 1687 & 5 \\
\hline$\underline{0}$ & 2 & 5 & 2.58 & & & & & $\overline{2}$ & 0 & 12 & 1.687 & $1.08 /$ & 5 & $1.08 /$ & 5 \\
\hline$\overline{2}$ & 1 & 1 & 2.54 & & & & & $\overline{3}$ & 0 & 8 & 1.645 & & & 1.644 & 5 \\
\hline$\underline{2}$ & 1 & 0 & 2.54 & & & 2.535 & 10 & $\overline{3}$ & 2 & 1 & 1.594 & 1592 & 5 & 1593 & 30 \\
\hline$\overline{2}$ & 1 & 2 & 2.53 & 2.53 & 7 & & & $\overline{3}$ & 2 & 2 & 1.592 & 1.592 & $\mathrm{~J}$ & 1.593 & 50 \\
\hline 1 & 1 & 7 & 2.52 & & & 2.530 & 5 & $\overline{3}$ & 2 & 3 & 1.583 & 1.581 & 4 & 1.582 & 10 \\
\hline 1 & 0 & 8 & 2.51 & & & & $\therefore$ & 1 & 0 & 14 & 1.573 & & & 1.575 & 10 \\
\hline 2 & 1 & 1 & 2.50 & & & 2,496 & 10 & $\overline{1}$ & 2 & 13 & 1.541 & & & & \\
\hline$\overline{1}$ & 2 & 4. & 2.50 & 2.50 & 6 & 2.490 & 10 & 0 & 4 & 0 & 1.540 & 1.540 & 7 & & \\
\hline$\overline{1}$ & 1 & 8 & 2.49 & & & & & $\overline{3}$ & 1 & 9 & 1.539 & & & & \\
\hline 2 & 1 & 2 & 2.43 & & & & & 3 & 2 & 3 & 1.533 & 1532 & & & \\
\hline 2 & 0 & 4 & 2.43 & 243 & 8 & & 20 & 2 & 3 & 5 & 1.532 & 1.532 & 0 & & \\
\hline 0 & 2 & 6 & 2.43 & 2.43 & 8 & 2.433 & 20 & 0 & 4 & 3 & 1.512 & 1.511 & 2 & & \\
\hline$\underline{0}$ & 1 & 9 & $2.42=$ & & & & & 1 & 4 & 0 & 1.484 & & & & \\
\hline$\overline{2}$ & 1 & 4 & 2.41 & & & 2.409 & 5 & $\underline{0}$ & & 11 & 1.484 & 1.484 & 3 & & \\
\hline$\frac{1}{1}$ & 2 & 4 & 2.41 & & & & $J$ & $\frac{1}{2}$ & 4 & 1 & 1.484 & & & & \\
\hline$\frac{1}{2}$ & $\begin{array}{l}2 \\
0\end{array}$ & $\begin{array}{l}5 \\
6\end{array}$ & $\begin{array}{l}2.39 \\
2.38\end{array}$ & 2.39 & 15 & 2.385 & 40 & $\begin{array}{l}1 \\
0\end{array}$ & & $\begin{array}{r}2 \\
16\end{array}$ & $\begin{array}{l}1.478 \\
1.477\end{array}$ & 1.477 & 3 & & \\
\hline 1 & 1 & 8 & 2.32 & & & 2320 & 5 & $\underline{2}$ & 2 & 11 & 1.437 & & & & \\
\hline$\overline{2}$ & 1 & 5 & 2.32 & 2.32 & 1 & 2.320 & 5 & $\overline{2}$ & 3 & 9 & 1.437 & 1.436 & $?$ & & \\
\hline 1 & 2 & 5 & 2.29 & 220 & 5 & 2296 & 20 & $\overline{3}$ & 1 & 11 & 1.436 & 1.456 & 2 & & \\
\hline 1 & 1 & 9 & 2.29 & 2.29 & 5 & 2.270 & 20 & 0 & 1 & 16 & 1.436 & & & & \\
\hline$\underline{0}$ & 2 & 7 & 2.28 & & & & & 3 & 1 & 9 & 1.411 & 1411 & 1 & & \\
\hline$\overline{1}$ & 2 & 6 & 2.27 & & & 2.269 & 5 & 1 & 3 & 11 & 1.411 & & & & \\
\hline 2 & 1 & 4 & 2.26 & & & & & 3 & 2 & 7 & 1.393 & & & & \\
\hline 0 & 1 & 10 & 2.21 & & & 2.200 & 10 & $\overline{2}$ & 3 & 10 & 1.393 & 1.392 & 2 & & \\
\hline$\overline{1}$ & 2 & 7 & 2.16 & & & & & 4 & 0 & 0 & 1.391 & & & & \\
\hline 2 & 1 & 5 & 2.15 & 2.16 & 15 & 2.154 & 40 & 2 & 0 & 14 & 1.384 & 1.383 & 2 & & \\
\hline 1 & 1 & 9 & 2.15 & & & & & & $a($ & $\bar{\AA})$ & 5.59 & (1) & & 5.598 & \\
\hline$\overline{2}$ & 0 & 8 & 2.13 & & & & & & $b($ & A) & 6.16 & (2) & & 6.121 & \\
\hline$\underline{0}$ & 2 & 8 & 2.13 & 2.13 & 7 & 2.130 & 10 & & $c($ & A) & 23.74 & (3) & & 23.762 & \\
\hline$\overline{2}$ & 1 & 7 & 2.12 & & & & & & $\beta($ & $\left.{ }^{\circ}\right)$ & 95.62 & (3) & & 95.55 & \\
\hline
\end{tabular}




\section{X-ray study}

Because of remarkable preferred orientation, the X-ray powder diffraction pattern for the ktenasite was obtained using a Gandolfi camera, $114.6 \mathrm{~mm}$ in diameter at the National Science Museum, Tokyo. The data were recorded on an Imaging Plate with $\mathrm{Ni}$-filtered $\mathrm{CuK \alpha}$ radiation, and processed with a Fuji BAS-2500 bioimaging analyzer and with a computer program by Nakamuta (1999). The refractions of ktenasite from Minoo were indexed on the monoclinic cell reported by Raade et al. (1977). The unit cell parameters calculated from the data with internal Si standard (NBS, $\# 640 \mathrm{~b})$ are $a=5.590(1), b=6.161(2), c=23.741(3) \AA$, and $\beta=95.628(3)^{\circ}$. The data are given in Table 1 , and compared with those of ktenasite from Norway (Raade et al., 1977).

\section{Chemical composition}

The chemical composition of ktenasite from Minoo was obtained using an electron microprobe analyzer (JEOL
JSM-5410LV+JED-2140) with the exception of $\mathrm{H}_{2} \mathrm{O}$. The accelerating voltage was $15 \mathrm{kV}$ and the beam current was $0.15 \mathrm{nA}$, and areas of approximately $5 \times 5$ $\mu \mathrm{m}$ were scanned for 100 seconds. The concentration of $\mathrm{H}_{2} \mathrm{O}$ was determined by a Perkin-Elmer CHNS/O analyzer (2400II) using a $2 \mathrm{mg}$ sample of handpicked crystals under a binocular microscope. The empirical formula of ktenasite from Minoo is $\left(\mathrm{Cu}_{3.446} \mathrm{Zn}_{1.451} \mathrm{Co}_{0.080}\right.$ $\left.\mathrm{Pb}_{0.018} \mathrm{Ni}_{0.007}\right)_{55.002}\left(\mathrm{SO}_{4}\right)_{2.003}(\mathrm{OH})_{5.998} \cdot 5.99 \mathrm{H}_{2} \mathrm{O}$ on the basis of $\mathrm{O}=20$. The results are given in Table 2, and compared with those reported by Kokkoros (1950), Raade et al. (1977), Olsen and Lewis (1979), Courtney and Rodgers (1990) and Livingstone (1991). Although a small part of $\mathrm{Cu}$ and/or $\mathrm{Zn}$ seems to be replaced by $\mathrm{Co}$, $\mathrm{Pb}, \mathrm{Ni}$, and $\mathrm{Fe}$, the chemical composition of ktenasite from Minoo is very close to those reported by Raade et al., (1977) and Courtney and Rodgers (1990). The chemical composition, for example the values of $\mathrm{H}_{2} \mathrm{O}$ and $\mathrm{SO}_{3}$, however, did not agree with analytical data reported by Kokkoros (1950) and Olsen and Lewis (1979). The mineral was also easily soluble in dilute hydrochloric acid, but insoluble in ammonia water.

Table 2. Chemical composition of ktenasite

\begin{tabular}{|c|c|c|c|c|c|c|}
\hline & 1 & 2 & 3 & 4 & 5 & 6 \\
\hline \multicolumn{7}{|c|}{ Weight percentages } \\
\hline $\mathrm{CuO}$ & 37.87 & 32.44 & 37.9 & 37.55 & 12.4 & 2.84 \\
\hline $\mathrm{ZnO}$ & 16.31 & $28.14 *$ & 16.6 & 16.29 & 48.0 & 52.96 \\
\hline $\mathrm{CoO}$ & 0.83 & ----- & ----- & ----- & ----- & ----- \\
\hline $\mathrm{PbO}$ & 0.54 & $-\cdots-$ & ----- & ---- & ----- & ---- \\
\hline $\mathrm{NiO}$ & 0.07 & ----- & ----- & ---- & ----- & ---- \\
\hline $\mathrm{FeO}$ & tr. & $-\cdots$ & --- & ----- & ----- & ----- \\
\hline $\mathrm{SO}_{3}$ & 22.15 & 19.92 & 24.0 & 22.7 & 22.0 & 21.97 \\
\hline $\mathrm{H}_{2} \mathrm{O}$ & 22.38 & 19.50 & 22.0 & $23.49 *$ & $17.6^{*}$ & 22.23 \\
\hline Total & 100.15 & 100.00 & 100.50 & 100.00 & 100.00 & 100.00 \\
\hline \multicolumn{7}{|c|}{ Mole ratios (basis : $\mathrm{O}=20$ ) } \\
\hline $\mathrm{Cu}$ & 3.446 & 3.158 & 3.402 & 3.341 & 1.224 & 0.262 \\
\hline $\mathrm{Zn}$ & 1.451 & 2.678 & 1.457 & 1.417 & 4.632 & 4.746 \\
\hline Co & 0.080 & ----- & ----- & ----- & ----- & ----- \\
\hline $\mathrm{Pb}$ & 0.018 & ----- & ----- & ----- & $-\cdots$ & ----- \\
\hline $\mathrm{Ni}$ & 0.007 & ---- & ----- & ----- & ----- & ---- \\
\hline $\mathrm{Fe}$ & ----- & ----- & $-\cdots$ & ----- & ----- & ---- \\
\hline $\mathbf{S}$ & 2.003 & 1.926 & 2.14 & 2.004 & 2.158 & 2.0 \\
\hline $\mathrm{H}$ & 17.982 & 16.766 & 17.44 & 18.458 & 15.342 & 18.0 \\
\hline \multicolumn{7}{|c|}{$\begin{array}{l}\text { 1. Hirao mine, Minoo, Osaka, Japan (The present work). } \\
\text { 2. Kamaresa mine, Lavrion, Greece (Kokkoros, 1950). } \\
\text { Zinc was not determined ; } \mathrm{H}_{2} \mathrm{O} \text { as loss on ignition. } \\
\text { 3. Glomsrudkollen zinc mine, Modum, Norway (Raade et al., 1977). } \\
\text { 4. Tui mine, Te Aroha, New Zealand (Courtney and Rodgers, 1990). } \\
\text { 5. Commodore mine, Creede, Colorado, USA (Olsen and Lewis, 1979). } \\
\mathrm{H}_{2} \mathrm{O} \text { was not determined. }\end{array}$} \\
\hline
\end{tabular}




\section{Discussion}

Kokkoros (1950) proposed the chemical formula of ktenasite from the type locality to be $(\mathrm{Cu}, \mathrm{Zn})_{3}\left(\mathrm{SO}_{4}\right)$ $(\mathrm{OH})_{4} \cdot 2 \mathrm{H}_{2} \mathrm{O}$. Subsequently, Olsen and Lewis (1979) confirmed the chemical formula. Raade et al. (1977), and Mellini and Merlino (1978), however, suggested that the chemical formula proposed by Kokkoros gave a value for calculated density as $3.26 \mathrm{~g} / \mathrm{cm}^{3}$, which was in poor agreement with the measured density $2.97 \mathrm{~g} / \mathrm{cm}^{3}$. Raade et al. (1977) and Courtney and Rodgers (1990) proposed the ideal chemical formula of $(\mathrm{Cu}, \mathrm{Zn})_{5}\left(\mathrm{SO}_{4}\right)_{2}$ $(\mathrm{OH})_{6} \cdot 6 \mathrm{H}_{2} \mathrm{O}$. The calculated density of ktenasite from Minoo was $2.96 \mathrm{~g} / \mathrm{cm}^{3}$, and is agreement with the measured density of $2.93 \mathrm{~g} / \mathrm{cm}^{3}$. The chemical formula of ktenasite from Minoo supports the formula proposed by Raade et al. (1977) and Courtney and Rodgers (1990). On the other hand, Mellini and Merlino (1978) determined the crystal structure of ktenasite from Italy as having a chemical formula of $\mathrm{Cu}_{5.2} \mathrm{Zn}_{4.8}$ $\left(\mathrm{SO}_{4}\right)_{4}(\mathrm{OH})_{12} \cdot 12 \mathrm{H}_{2} \mathrm{O}$. The ktenasite structure was shown to contain two copper sites of $\mathrm{Cu}(1)$ and $\mathrm{Cu}(2)$ into which zinc enters, and a pure zinc site also; $\mathrm{Zn}_{2}(\mathrm{Cu}(1), \mathrm{Zn})_{4}(\mathrm{Cu}(2), \mathrm{Zn})_{4}\left(\mathrm{SO}_{4}\right)_{4}(\mathrm{OH})_{12} \cdot 12 \mathrm{H}_{2} \mathrm{O}$. They also showed that copper atoms in the $\mathrm{Cu}(1)$ site are probably replaced by zinc atoms at higher degree than in $\mathrm{Cu}(2)$ site. Therefore, assuming that zinc atoms except the pure zinc site occupy in $\mathrm{Cu}(1)$ site, the empirical formula of ktenasite from Minoo can be rewritten $\mathrm{Zn}_{2.000}\left(\mathrm{Cu}(1)_{2.892} \mathrm{Zn}_{0.902} \mathrm{Co}_{0.160} \mathrm{~Pb}_{0.036} \mathrm{Ni}_{0.014}\right)_{\Sigma 4.004}$ $\mathrm{Cu}(2)_{4.000}\left(\mathrm{SO}_{4}\right)_{4.006}(\mathrm{OH})_{11.996} \cdot 11.98 \mathrm{H}_{2} \mathrm{O}$ on the basis of $\mathrm{O}$ $=40$. $\mathrm{Cu} /(\mathrm{Cu}+\mathrm{Zn})$ ratio of ktenasite from Minoo shows 0.704 which is nearly equal to those reported by Raade et al. (1977) and Courtney and Rodgers (1990).

Ktenasite from Minoo occurs as a vein and in a marginal part of sphalerite in the altered shale, and it is closely associated with sphalerite, and $\mathrm{H}_{2} \mathrm{O}$ bearing secondary minerals, such as serpierite, ramsbeckite, hydrozincite, and schulenbergite. The occurrence at Minoo shows that $\mathrm{Cu}$-bearing fluids intruded into the altered shale after mineralization of the ore such as sphalerite, chalcopyrite and so on. It is likely that ktenasite was formed by a reaction of the fluids with sphalerite.

\section{Acknowledgments}

We would like to express our thanks to Mr. H. Sakurai and Mr. S. Aoki for fieldwork conducted, to Dr. R. Miyawaki of National Science Museum for carrying out the Gandolfi camera experiments, and to Mr. L. Anthony of Okayama University of Science for proofreading the final manuscript. The authors also thank Dr. S. Matsubara and Dr. S. Uehara for their valuable suggestions concerning this paper.

\section{References}

Adiwidjaja, G., Friese, K., Klaska K.-H. and Schlüer, J. (1996) The crystal structure of christelite $\mathrm{Zn}_{3} \mathrm{Cu}_{2}\left(\mathrm{SO}_{4}\right)_{2}(\mathrm{OH})_{6} \cdot 4 \mathrm{H}_{2} \mathrm{O}$. Zeitschrift für Kristallographie, 211, 518-521.

Courtney, S.F. and Rodgers, K.A. (1990) Ktenasite, $(\mathrm{Cu}, \mathrm{Zn})_{5}$ $\left(\mathrm{SO}_{4}\right)_{2}(\mathrm{OH})_{6} \cdot 6 \mathrm{H}_{2} \mathrm{O}-$ a further occurrence. Neues Jahrbuch für Mineralogie Monatshefte, 320-326.

Kokkoros, P. (1950) Ktenasit, ein Zink-Kupfersulfat aus Lavrion (Griechenland). Tschermaks Mineralogische und Petrographische Mitteilungen, 1, 342-346.

Livingstone, A. (1991) The zinc analogue of ktenasite from Smallcleugh and Brownley Hill mines, Nenthead, Cumbria. Journal of Russell Society, 4, 13-15.

Mellini, M. and Merlino, S. (1978) Ktenasite, another mineral with $\left.{ }_{\infty}^{2}[(\mathrm{Cu}, \mathrm{Zn})]_{2}(\mathrm{OH})_{3} \mathrm{O}\right]^{-}$octahedral sheets. Zeitschrift für Kristallographie, 147, 129-140.

Mellini, M., Orlandi, P. and Boscardin, M. (1981) Chemical and crystallographic data for ktenasite. Rendiconti Società Italiana di Mineralogia e Petrologia, 37, 409-414.

Nakamuta, Y. (1999) Precise analysis of a very small mineral by an Xray diffraction method. Journal of the Mineralogical Society of Japan, 28, 117-121 (in Japanese with English abstract).

Ohnishi, M., Shirakami, M. and Yoshimura, T. (2001) Secondary minerals from the Hirao Old Mine, Onsen-cho, Minoo City, Osaka Prefecture, Japan. Chigaku Kenkyu, 50, 137-159 (in Japanese).

Olsen, E. and Lewis, C.F. (1979) Ktenasite from Creede, Colorado. American Mineralogist, 64, 446-448.

Raade, G., Elliott, C. J. and Fejer, E. E. (1977) New data on ktenasite. Mineralogical Magazine, 41, 65-70.

Rankin, J.B.Jr. (1969) The mineralogy of the Ecton Mine, Montgomery County, Pennsylvania. Rocks and Minerals, 44, 594-595.

Sarp, H., Perround, P. and Camerola, M. (1990) Cobalt nickelkténasite de la mine Cap Garonne (Var), France, nouvelle variété de kténasite. Schweizerische Mineralogische und Petrographische Mitteilungen, 70, 333-335.

Manuscript received; 22 March, 2002

Manuscript accepted; 9 July, 2002 